\title{
PENGARUH MODEL PEMBELAJARAN KOOPERATIF TALKING STICK BERBANTUAN MIND MAPPING TERHADAP KEMAMPUAN KOMUNIKASI MATEMATIKA SISWA PADA MATERI BANGUN RUANG SISI DATAR KELAS VIII SMP NEGERI 6 SINGARAJA
}

\author{
I.A.D. Wulandari, I.G.N. Pujawan, I.M. Suarsana \\ Jurusan Pendidikan Matematika, Universitas Pendidikan Ganesha \\ Singaraja, Indonesia \\ e-mail: idaayudewiwulandari@gmail.com , ngrpujawan@yahoo.com , suarsana1983@gmail.com
}

\begin{abstract}
Abstrak
Penelitian ini bertujuan untuk mengetahui apakah kemampuan komunikasi matematika siswa yang dibelajarkan dengan model pembelajaran Talking Stick Berbantuan Mind Mapping lebih baik daripada kemampuan komunikasi matematika siswa yang dibelajarkan dengan pembelajaran konvensional. Jenis penelitian ini adalah eksperimen semu dengan desain penelitian Post Test Only Control Group Design. Populasi penelitian ini adalah seluruh siswa Kelas VIII Non Unggulan Semester Genap SMP Negeri 6 Singaraja Tahun Ajaran 2016/2017 dengan jumlah 293 siswa yang terdistribusi ke dalam 10 kelas. Pengambilan sampel dilakukan dengan teknik cluster random sampling untuk memperoleh 2 kelas sebagai sampel penelitian. Kemudian dari 2 kelas sampel diundi lagi untuk menentukan kelas eksperimen dan kelas kontrol. Data kemampuan komunikasi matematika siswa diperoleh menggunakan tes dengan bentuk uraian. Skor rata-rata kemampuan komunikasi matematika kelas eksperimen yaitu 65,57 sedangkan skor rata-rata kemampuan komunikasi matematika kelas kontrol yaitu 58,53. Data dianalisis menggunakan Uji-t satu ekor pada taraf signifikan $5 \%$. Hasil uji hipotesis menunjukkan bahwa $t_{\text {hitung }}=2,11$ lebih dari $t_{\text {tabel }}=1,671$, sehingga $H_{0}$ ditolak. Dengan demikian dapat disimpulkan bahwa kemampuan komunikasi matematika siswa yang dibelajarkan dengan model pembelajaran Talking Stick Berbantuan Mind Mapping lebih baik daripada kemampuan komunikasi matematika siswa yang dibelajarkan dengan pembelajaran konvensional.
\end{abstract}

Kata kunci: Talking Stick, Mind Mapping, Kemampuan Komunikasi Matematika

\begin{abstract}
This research was aimed to determine whether mathematical communication skill of students who were taught by Talking Stick learning model assisted by mind mapping was better than mathematical communication skill of students who were taught by conventional learning. This research is a quasi experimental which research design used post test only control group design. The population of this study was the eighth grade students of SMP Negeri 6 Singaraja non-excellent class and even semester in academic year 2016/2017 which with a total population of 293 students spreading into ten classes. The sample was taken by random sampling technique, there were two classes samples research. Then, from two classes are drawn for taken as samples that experimental and control class. The data mathematical communication skill of students was obtained using an essay test. The average score of mathematical communication skill of students in experimental class is 65,57 and the average score of mathematical communication skill of students in control class is 58,53 . The research data were analyzed by using one tailed t-test with the significant level of $5 \%$. The result of the hypothesis shows that $t_{\text {value }}=2,11$ is greater than $t_{\text {table }}=1,671$, so that $\mathrm{H}_{0}$ is rejected. Based on the result, the conclusion is the mathematical communication skill of students who are taught by Talking Stick learning model assisted by mind mapping is better than mathematical communication skill of students who are taught by conventional learning.
\end{abstract}

Keywords : Talking Stick, Mind Mapping, Mathematical Communication Skil 


\section{PENDAHULUAN}

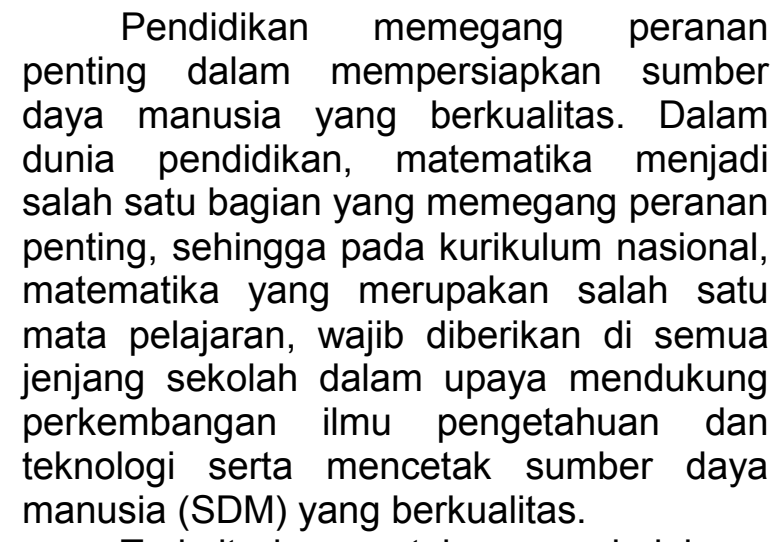

Terkait dengan tujuan pembelajaran berdasarkan Lampiran I Peraturan Menteri Pendidikan Nasional No.22 Tahun 2006 tentang Standar Isi untuk Satuan Pendidikan Dasar dan Menengah di mana salah satunya yaitu mengomunikasikan gagasan dengan simbol, tabel, diagram, atau media lain untuk memperjelas keadaan atau masalah. (Depdiknas, 2006) Hal tersebut menjelaskan bahwa kemampuan komunikasi adalah salah satu bagian penting dalam pembelajaran matematika. Baroody (1993) menyebutkan bahwa sedikitnya ada dua alasan penting mengapa komunikasi dalam pembelajaran matematika perlu dikembangkan di sekolah yaitu (1) mathematics is essentially a language; matematika tidak hanya sekedar alat bantu berpikir, alat menemukan pola, menyelesaikan masalah, atau membuat kesimpulan, matematika juga adalah alat yang tak terhingga nilainya untuk mengkomunikasikan berbagai ide dengan jelas, tepat, dan ringkas, (2) mathematics and mathematics learning are, at heart, social activities; sebagai aktivitas sosial dalam pembelajaran matematika, interaksi antara siswa, seperti komunikasi antar guru dan siswa, adalah penting untuk mengembangkan potensi matematika siswa. Begitu pentingnya komunikasi matematika yang dapat mengembangkan pemahaman siswa terhadap pembelajaran matematika. Selain itu, komunikasi matematika dapat melatih siswa untuk berpikir dan bernalar tentang matematika dan untuk mengkomunikasikan hasil pikiran mereka kepada yang lain secara tertulis atau lisan sehingga mereka berlatih untuk menjelaskan, mengemukakan pendapat, dan mempertanggungjawabkan. Menurut
Sullvian dan Mousley (1996) komunikasi matematika bukan hanya sekedar menyatakan ide melalui tulisan tetapi lebih luas lagi yaitu kemampuan siswa dalam bercakap, menjelaskan, menggambarkan, mendengar, menanyakan, klarifikasi, bekerja sama (sharing), menulis, dan akhirnya melaporkan apa yang telah dipelajari. Dengan demikian komunikasi matematika merupakan kemampuan siswa dalam menyampaikan ide secara lisan atau tertulis, serta kemampuan siswa dalam menginterpretasikan gambar, grafik, tabel, dan sajian fisik.

Beberapa fakta berdasarkan hasil yang diperoleh siswa Indonesia di ajang TIMSS tahun 2015, siswa Indonesia kelas IV memperoleh skor rata-rata pada bidang matematika yaitu 397 yang masih jauh dari negara lain dengan skor rata-rata tertinggi yaitu 618 . Indonesia berada pada peringkat 51 dari 55 negara yang ikut serta. Jakfar et al. (2015) menyebutkan dalam menganalisis soal pada ajang TIMSS tahun 2015 bahwa ada dua domain yang diujikan yaitu domain konten dan domain kognitif. Domain kognitif terdiri atas tiga bagian yaitu pengetahuan, penerapan dan penalaran. Ketiga bagian dari domain kognitif tersebut sangat berhubungan dengan kemampuan komunikasi matematika. Rendahnya peringkat Indonesia dalam studi TIMSS tersebut merupakan gambaran keadaan bahwa siswa Indonesia belum mampu mengembangkan kemampuan komunikasi matematika secara maksimal. Begitu pula menurut Lemahnya kemampuan komunikasi matematis ini juga dibuktikan oleh hasil studi PISA (Programme International for Student Assesment) pada tahun 2015 yang menyatakan bahwa Indonesia memperoleh skor rata-rata 386 dengan skor rata-rata tertinggi 564 yang menjelaskan bahwa Indonesia pada bidang matematika berada pada peringkat 63 dari 70 negara yang ikut serta. Shiel et al. (2007) menyebutkan bahwa PISA mengidentifikasi delapan tipe dari proses kognitif yang terkait dalam matematika yakni (1) penalaran, (2) argumentasi, (3) komunikasi, (4) pemodelan, (5) perumusan dan pemecahan masalah, (6) representasi, (7) penggunaan simbol, bahasa, operasi serta teknis yang formal, (8) penggunaan 
bantuan dan alat. PISA membedakan tingkat kesulitan pada tesnya menjadi 6 level, di mana dari level 3 sampai level 6 yang dijelaskan pada PISA, menunjukkan kemampuan komunikasi matematis siswa.

Dari uraian yang telah dipaparkan tersebut, perlu adanya suatu upaya untuk meningkatkan kemampuan komunikasi matematika siswa. Para ahli pendidikan telah banyak mengemukakan serta mengenalkan model pembelajaran untuk lebih mengefektifkan pembelajaran di kelas. Model pembelajaran yang dapat diterapkan dalam pembelajaran matematika adalah model pembelajaran kooperatif talking stick. Model pembelajaran kooperatif ini dapat mendorong terjadinya komunikasi yang aktif melalui kegiatan diskusi, pengajuan pertanyaan, mendengarkan secara aktif dan mempresentasikan, khususnya pada model pembelajaran kooperatif tipe talking stick adalah suatu model pembelajaran kooperatif yang dapat mendorong siswa untuk berani mengemukakan pendapat. Model pembelajaran ini dilakukan dengan bantuan stick dengan panjang $20 \mathrm{~cm}$. Siswa yang memegang stick wajib menjawab pertanyaan dari guru setelah siswa mempelajari materi pokoknya. Selain untuk melatih berbicara dan mengemukakan pendapatnya, pembelajaran ini akan menciptakan suasana yang menyenangkan dan membuat siswa aktif.

Pada langkah awal dalam model pembelajaran talking stick, guru hanya menginformasikan materi pokok saja, dan siswa diminta untuk mempelajari sendiri sebelum tongkat akan dikelilingkan. Bagi siswa yang tidak cepat memahami materi pelajaran, hal ini akan membuat siswa merasa khawatir ketika giliran tongkat berada pada tangannya dan siswa tersebut tidak dapat menjawab pertanyaan dari guru. Hal ini dikarenakan kurangnya persiapan dalam memahami materi. Oleh karena itulah dalam proses pembelajarannya perlu adanya bantuan mind mapping. Menginformasikan materi melalui bagan yang dinamakan dengan mind mapping sehingga dalam langkah awal pembelajaran membantu siswa lebih memahami dan mengingat materi. Selain itu, siswa juga diminta untuk melatih diri dalam membuat mind mapping. Menurut Iwan (2004:74), "Mind mapping (peta pikiran) adalah teknikmeringkas konsep yang telah dipelajari dan memproyeksikan masalah yang dihadapi ke dalam bentuk peta atau teknik grafik sehingga lebihmudah memahaminya". Sedangkan menurut Windura (2008:16), "Mind mapping merupakan teknik grafis yang memungkinkan kita untuk mengeksplorasi seluruh kemampuan otak untuk keperluan berpikir dan belajar". Berdasarkan uraian tersebut, mind mapping dapat diartikan sebagai suatu teknik pembelajaran yang memanfaatkan kerja alami otak kanan dan otak kiri secara seimbang melalui proses mencatat dan meringkas yang dapat membantu mengingat perkataan, bacaan, meningkatkan pemahaman terhadap materi, membantu mengorganisasikan materi dan memberikan wawasan baru.

$$
\text { Perpaduan antara model }
$$
pembelajaran talking stick dengan mind mapping dalampembelajaran matematika dapat dilihat pada tahap pembelajarannya, yaitu guru menginformasikan materi secara singkat dalam bentuk bagan-bagan yang dinamakan dengan mind mappingdan siswa perlu memahami materi tersebut. Sembari memahami penjelasan dari guru, siswa diberikan kesempatan untuk membaca kembali dan berdiskusi dengan anggota kelompoknya, kemudian guru melaksanakan tahap pada model pembelajaran talking stickyaitu meminta siswa yang memperoleh giliran memegang stick untuk mengomunikasikan atau menjawab pertanyaan yang diberikan oleh guru, untuk pembelajaran/langkah selanjutnya siswa diminta untuk melatih diri dalam membuat mind mappingatau mengkonstruksi pengetahuannya sendiri yang didapat dari proses sebelumnya yang dituangkan dalam bentukmind mapping secara berkelompok. Dengan demikian, siswa mampu memahami sendiri bagaimana materi yang akan dipelajari, dapat menuliskan struktur, notasi, ataupun istilah-istilah dengan benar dalam sebuah mind mapping. Melalui melatih dalam membuat mind mappingmerupakan langkah dalam menuliskan kembali ide matematika dengan bahasanya sendiri yang 
mencerminkan dalam kemampuan komunikasi siswa secara tertulis.

Berdasarkan hasil penelitian yang dilakukan oleh Yunita (2014) di SMP Negeri 2 Tanjungsari-Sumedang yang berdasarkan hasil penelitiannya menunjukkan bahwa, peningkatan kemampuan komunikasi matematik siswa yang memperoleh pembelajaran dengan model pembelajaran talking stick memilki nilai rata-rata sebesar 0,54 dan memiliki kriteria peningkatan sedang. Sedangkan peningkatan kemampuan komunikasi matematik siswa yang memperoleh pembelajaran dengan menggunakan pembelajaran konvensional memiliki nilai rata-rata sebesar 0,35 dan memiliki kriteria peningkatan sedang. Selain itu, terdapat perbedaan peningkatan kemampuan komunikasi matematik siswa antara yang menggunakan model pembelajaran talking stickdengan yang menggunakan pembelajaran konvensional. Serta sikap siswa terhadap pembelajaran matematika dengan menggunakan model pembelajaran talking stickmenunjukkan sikap positif.

Sementara penelitian yang terkait dengan mind mapping dalam pembelajaran dapat dilihat dari penelitian yang dilakukan oleh Wowiling (2013) mengenai Metode Pemetaan Pikiran menunjukkan bahwa penerapan metode pemetaan pikiran (mind mapping) memberikan pengaruh yang positif terhadap penguasaan konsep siswa. Hal ini terlihat dari hasil analisisnya di mana dengan menggunakan uji $t$ hasil perhitungan perbedaan rata-rata post test kedua kelompok diperoleh $t$ hitung lebih besar dari $t$ tabel sebesar $(1,843>1,560)$ yang berarti terdapat perbedaan penguasaan konsep yang signifikan setelah penerapan pembelajaran dengan metode pemetaan pikiran (mind mapping) pada kelas eksperimen, dan pembelajaran dengan Metode Diskusi pada kelas kontrol.

Dari uraian tersebut, dalam mengukur kemampuan komunikasi matematika, siswa yang dibelajarkan dengan model pembelajaran kooperatif talking stick memperoleh hasil yang lebih baik daripada siswa yang dibelajarkan dengan pembelajaran konvensional. Begitu pula dengan mind mappingyang menunjukkan pengaruh positif dalam pembelajaran matematika, dan secara teoritis model pembelajaran talking stick yang dipadukan dengan mind mapping dirasa efektif dalam pembelajaran matematika dilihat dari langkah-langkah pembelajarannya untuk meningkatkan kemampuan komunikasi matematika siswa karena perpaduannya yang akan dilaksanakan dalam pembelajaran matematika memberikan kesempatan kepada siswa untuk berani mengomunikasikan ide-ide matematika dan meningkatkan pemahaman siswa sehingga lebih mudah dalam mengomunikasikan secara tertulis. Berdasarkan hal tersebut, dipandang perlu untuk mendapatkan bukti empiris tentang pengaruh model pembelajaran kooperatif talking stick berbantuan mind mapping terhadap kemampuan komunikasi matematika siswa. Oleh karena itu dilakukan penelitian yang berjudul "Pengaruh Model Pembelajaran Kooperatif Talking Stick Berbantuan Mind Mapping terhadap Kemampuan Komunikasi Matematika Siswa pada Materi Bangun Ruang Sisi Datar Kelas VIII SMP Negeri 6 Singaraja"

\section{METODE}

Penelitian ini merupakan penelitian eksperimen yang bertujuan untuk menguji pengaruh model pembelajaran talking stick berbantuan mind mapping terhadap kemampuan komunikasi matematika siswa kelas VIII SMP Negeri 6 Singaraja. Penelitian ini merupakan eksperimen semu karena peneliti tidak dapat mengontrol semua variabel dan kondisi eksperimen secara ketat (Sugiyono, 2012).

Populasi dalam penelitian ini yaitu siswa kelas VIII SMP Negeri 6 Singaraja non unggulan semester genap tahun ajaran 2015/2016 berjumlah 293 siswa yang terdistribusi ke dalam 10 kelas yaitu kelas VIII B1, VIII B2, VIII B3, VIII B4, VIII B5, VIII B6, VIII B7, VIII B8, VIII B9, dan VIII B10. Kesepuluh kelas tersebut setara secara akademik karena dalam pengelompokan siswa ke dalam kelas-kelas, siswa disebar secara merata antara siswa yang memiliki kemampuan tinggi, sedang, dan rendah. Hal ini berdasarkan hasil wawancara dengan Wakil Kepala Sekolah bidang kurikulum yang menjelaskan bahwa seluruh 
siswa kelas VIII Non Unggulan tersebar secara random. Pengambilan sampel dilakukan dengan teknik random sampling yaitu teknik pemilihan sampel yang dilakukan secara acak. Dari 10 kelas populasi pada penelitian ini diambil dua kelas sampel. Cara pengambilan kelas sampel dalam sistem undian tersebut adalah kedua kelas yang muncul dalam undian langsung dijadikan sebagai kelas sampel, di mana diperoleh kelas VIII B4 dan kelas VIII B6 sebagai kelas sampel. Kemudian dari dua kelas tersebut diundi kembali untuk menentukan kelas eksperimen dan kelas kontrol dan diperoleh kelas VIII B6 sebagai kelompok eksperimen dan kelas VIII B4 sebagai kelompok kontrol.

Desain penelitian yang digunakan dalam penelitian ini adalah "Post Test Only Control Group Design" yang digambarkan seperti tabel 1 di bawah ini.

Tabel 1. Desain Penelitian

\begin{tabular}{ccc}
\hline Kelompok & Perlakuan & Post Test \\
Eksperimen & $X$ & $Y_{1}$ \\
Kontrol & - & $Y_{2}$ \\
\hline
\end{tabular}

(dimodifikasi dari Sugiyono, 2010)

Keterangan:

$X$ : Perlakuan perlakuan berupa penerapan model pembelajaran Talking Stick berbantuan Mind Mapping

$Y_{1}$ : Hasil Post-test untuk kelas eksperimen

$Y_{2}$ : Hasil Post-test untuk kelas kontrol Instrumen yang digunakan dalam mengumpulkan data untuk mengukur kemampuan komunikasi matematika siswa yaitu tes kemampuan komunikasi matematia berbentuk soal uraian (essay). Salanjutnya instrumen diujicobakan untuk mengetahui gambaran secara empirik apakah tes kemampuan komunikasi matematika siswa tergolong instrumen yang baik dan dapat digunakan dalam penelitian atau tidak. Langkah pertama sebelum dilakukan uji coba instrumen yaitu pengujian validitas isi melalui uji pakar. Hasil uji pakar menunjukkan bahwa instrumen yang disusun tergolong sangat relevan. Selanjutnya, soal tersebut diujicobakan kepada siswa kelas VIII-4
SMP laboratorium UNDIKSHA. Data hasil uji coba instrumen yang berupa skor kemampuan komunikasi matematika siswa kemudian dianalisis validitas butir soalnya menggunakan rumus korelasi product moment (Candiasa, 2010a) dan reliabilitas tes diuji menggunakan rumus Alpha Cronbach (Candiasa, 2010a) yang menghasilkan tiap butir soal tergolong valid dan memiliki reliabilitas sangat tinggi.

Kelompok sampel yang telah diberikan perlakuan dan diperoleh data hasil post test tersebut dilakukan pengujian terhadap hipotesis yang diajukan. Namun, sebelumnya, terlebih dahulu dilakukan uji normalitas dan homogenitas terhadap data yang diperoleh sebagai prasyarat pengujian hipotesis. Data yang digunakan yaitu berupa nilai kemampuan komunikasi matematika dari kedua kelompok sampel. Pengujian normalitas sebaran data nilai kemampuan komunikasi matematika siswa menggunakan uji liliefors sedangkan untuk pengujian varians kedua kelompok digunakan rumus uji-F. Kemudian pengujian terhadap hipotesis menggunakan uji-t satu ekor pada taraf signifikansi $5 \%$. Pengujian hipotesis dengan menggunakan uji-t satu ekor dilakukan untuk mengetahui apakah kemampuan komunikasi matematika siswa yang dibelajarkan dengan model pembelajaran Talking Stick berbantuan mind mapping lebih baik daripada kemampuan komunikasi matematika siswa yang dibelajarkan dengan pembelajaran konvensional. Adapun rumus uji-t yang digunakan yaitu sebagai berikut.

$$
t_{h i t}=\frac{\bar{Y}_{1}-\bar{Y}_{2}}{\sqrt{\frac{S^{2}}{n_{1}}+\frac{S^{2}}{n_{2}}}}
$$

dengan

$$
S^{2}=\frac{\left(n_{1}-1\right) S_{1}^{2}+\left(n_{2}-1\right) S_{2}^{2}}{\left(n_{1}+n_{2}-2\right)}
$$

Keterangan:

(Candiasa, 2010b)

$\bar{Y}_{1} \quad=$ rata-rata skor dari kelas eksperimen

$\bar{Y}_{2} \quad$ =rata-rata skor dari kelas kontrol

$S^{2} \quad$ =simpangan baku gabungan 


$\begin{array}{ll}S_{1} & \begin{array}{l}\text { =simpangan baku dari kelas } \\ \text { eksperimen }\end{array} \\ S_{2} & \begin{array}{l}\text { =simpangan baku dari kelas } \\ n_{1}\end{array} \\ & =\text { banyak subjek dari kelas } \\ n_{2} & =\text { eksperimen }\end{array}$

\section{HASIL DAN PEMBAHASAN}

Data kemampuan komunikasi matematika siswa diperoleh dari post test yang telah diberikan kepada kelas eksperimen dan kelas kontrol. Adapun rangkuman hasilnya ditunjukkan oleh tabel 2 di bawah ini.

Tabel 2. Rangkuman analisis data kemampuan komunikasi matematika siswa pada kelompok eksperimen dan kelompok kontrol

\begin{tabular}{|c|c|c|c|}
\hline \multirow[b]{2}{*}{ No } & \multirow{2}{*}{ Variabel } & \multicolumn{2}{|c|}{ Kelompok } \\
\hline & & Eksperimen & Kontrol \\
\hline 1 & $\begin{array}{l}\text { Banyak } \\
\text { Siswa (n) }\end{array}$ & 28 & 30 \\
\hline 2 & $\begin{array}{l}\text { Rata-rata } \\
(\bar{Y})\end{array}$ & 65,57 & 58,53 \\
\hline 3 & $\begin{array}{l}\text { Standar } \\
\text { Deviasi } \\
\text { (s) }\end{array}$ & 11,867 & 13,765 \\
\hline
\end{tabular}

Berdasarkan hasil analisis data pada tabel 2 di atas, terlihat bahwa bahwa ratarata skor kemampuan komunikasi matematika siswa kelompok eksperimen yang dibelajarkan dengan model pembelajaran talking stick berbantuan mind mapping lebih tinggi dari rata-rata skor kemampuan komunikasi matematika siswa kelompok kontrol yang mengikuti pembelajaran konvensional.

$$
\text { Untuk mengetahui apakah }
$$
kemampuan komunikasi matematika siswa yang dibelajarkan dengan model pembelajaran talking stick berbantuan mind mapping lebih baik dari kemampuan komunikasi matematika siswa yang mengikuti pembelajaran konvensional, maka perlu pengujian terhadap $H_{0}$. Sebelum uji hipotesis dilakukan, terlebih dahulu dilakukan pengujian terhadap normalitas dan homogenitas varians terhadap skor kemampuan komunikasi matematika siswa. Rangkuman hasil uji normalitas data pada kelompok eksperimen dan kelompok kontrol dapat dilihat pada Tabel 3 berikut.

Tabel 3. Rangkuman Hasil Uji Normalitas Skor Kemampuan Komunikasi Matematika Siswa

\begin{tabular}{cccc}
$\begin{array}{c}\text { Kelompok } \\
\text { Sampel }\end{array}$ & L $_{\text {hitung }}$ & L tabel & Ket. \\
Eksperimen & 0,12 & 0,14 & Normal \\
Kontrol & 0,11 & 0,161 & Normal \\
\hline
\end{tabular}

Dari Tabel 3 diatas, terlihat bahwa Lnitung pada kedua kelompok sampel baik eksperimen maupun kontrol lebih kecil dari $L_{\text {tabel }}$ pada kelompok yang bersangkutan, sehingga $H_{0}$ diterima dengan kesimpulan bahwa data kemampuan komunikasi matematika siswa berasal dari populasi yang berdistribusi normal. Adapun rangkuman hasil pengujian homogenitas varians sebaran data skor kemampuan komunikasi matematika siswa untuk kedua kelompok sampel dengan Uji-F dapat dilihat pada 4 berikut.

Tabel 4. Rangkuman Hasil Uji Homogenitas Varians Skor Kemampuan Komunikasi Matematika Siswa

\begin{tabular}{cccc}
$\begin{array}{c}\text { Kelompok } \\
\text { Sampel }\end{array}$ & Varians & $\mathbf{F}_{\text {hitung }}$ & $\mathbf{F}_{\text {tabel }}$ \\
Eksperimen & 140,85 & & \\
Kontrol & 189,5 & 1,34 & 1,8751 \\
\hline
\end{tabular}

Dari Tabel 4 tersebut, dapat dilihat bahwa $F_{\text {hit }}<F_{\text {tabel }}$, untuk taraf signifikansi $5 \%, \quad 27=\mathrm{dk}$ penyebut dan 29=dk pembilang Dengan demikian $H_{0}$ diterima dengan kesimpulan bahwa data kemampuan komunikasi matematika diperoleh dari varians yang homogen.

Karena uji prasyarat sudah terpenuhi, maka pengujian hipotesis dapat dilakukan dengan menggunakan Uji-t satu ekor. Secara statistik hipotesis tersebut dapat dirumuskan sebagai berikut.

$$
\begin{array}{ccc}
H o: \mu_{1} \leq \mu_{2} & \text { melawan } H_{1}: \mu_{1}>\mu_{2} \\
\text { Ho: } \mu_{1} \leq \mu_{2} & \text { menunjukkan } & \text { kemampuan } \\
& \text { komunikasi } & \text { matematika } \\
& \text { siswa yang } & \text { dibelajarkan }
\end{array}
$$




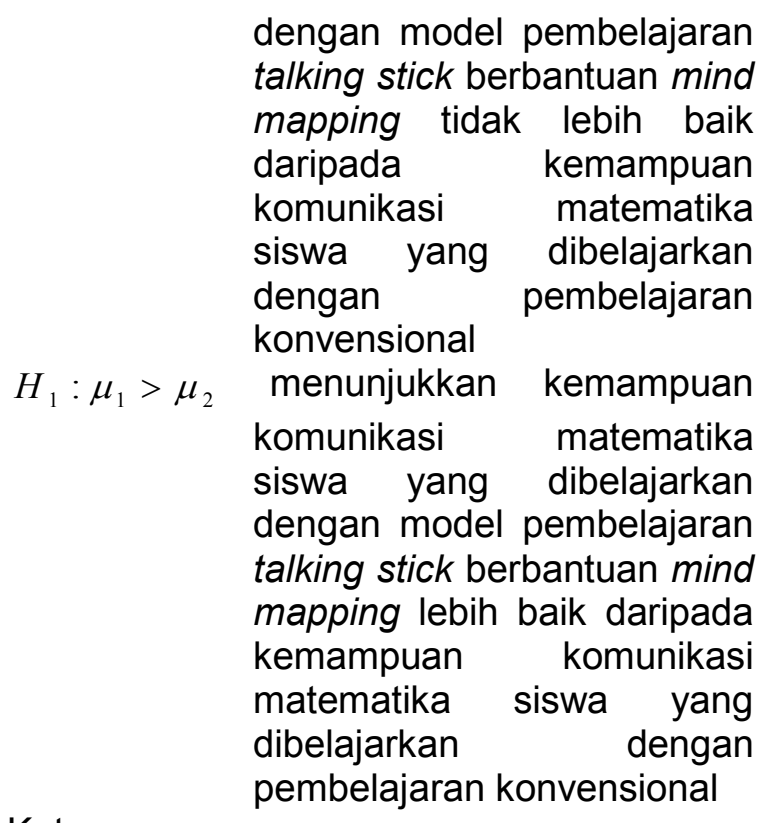

Keterangan:

$\mu_{1} \quad=$ rata-rata kemampuan komunikasi matematika siswa yang dibelajarkan dengan model pembelajaran talking stick berbantuan mind mapping

$\mu_{2} \quad$ =rata-rata kemampuan komunikasi matematika siswa yang mengikuti pembelajaran konvensional.

Adapun rangkuman hasil uji-t data kemapuan komunikasi matematika siswa dapat dilihat pada 5 berikut.

Tabel 5. Rangkuman Hasil Hasil Uji-T Data Kemapuan Komunikasi Matematika Siswa

\begin{tabular}{lccccc}
\hline Kelompok & $\mathbf{n}$ & $\bar{Y}$ & $s_{\text {gab }}^{2}$ & $t_{\text {hitung }}$ & $t_{\text {tabel }}$ \\
& & & & & \\
Eksperimen & 28 & 65,57 & 161,51 & 2,11 & 1,67 \\
Kontrol & 30 & 58,53 & & \\
\hline
\end{tabular}

Berdasarkan hasil perhitungan pada

Tabel 5, diperoleh bahwa nilai $t_{\text {hitung }}>t_{\text {tabel }}$, sehingga $H_{0}$ ditolak. Dengan demian dapat disimpulkan bahwa kemampuan komunikasi matematika siswa yang dibelajarkan dengan model pembelajaran talking stick berbantuan mind mapping lebih baik daripada kemampuan komunikasi matematika siswa yang dibelajarkan dengan pembelajaran konvensional.

Lebih baiknya kemampuan komunikasi matematika siswa pada kelompok eksperimen dikarenakan dalam pelaksanaan proses pembelajaran siswa lebih besar memiliki kesempatan untuk mengomunikasikan ide-ide matematika melalui langkah pembelajaran model pembelajaran talking stick berbantuan mind mapping yang dimana pada langkah tersebut terdapat langkah berdiskusi dalam kegiatan berkelompok, kemudian terdapat langkah di mana siswa memperoleh peluang yang sama untuk menjawab pertanyaan dari guru, bukan hanya siswa yang memiliki prestasi tinggi lebih dominan untuk mengerjakan soal di papan. Mengomunikasikan ide-ide matematika secara tertulis melalui langkah memahami mind mapping yang diberikan dan melatih membuat mind mapping yang dapat membantu ingatan siswa terhadap materi yang dipelajari sehingga nantinya siap ketika memperoleh giliran menjawab pertanyaan dari guru.

Tahapan awal pada model pembelajaran talking stick berbantuan mind mapping yakni persiapan dan menginformasikan materi secara singkat melalui mind mapping yang telah dibuat dan dipersiapkan sebelumnya oleh guru itu sendiri.

Tahapan berikutnya adalah tahapan diskusi secara berkelompok, siswa mampu berbagi informasi, mengomunikasikan materi dan berbagii pendapat mengenai masalah yang diberikan oleh guru yang dibantu dengan Lembar Kerja Kelompok (LKK). Dalam hal ini siswa harus berperan aktif dalam mengajukan pendapat, bertukar pikiran, dan mengajarkan temannya apabila ada yang belum dimengerti.

Setelah melalui tahap diskusi, tahapan pembelajaran dilakukan dengan memberikan kesempatan kepada siswa untuk menjawab pertanyaan dari guru. Hal ini dilakukan guna mengecek sejauh mana pemahaman siswa terhadap materi yang dipelajari. Selain itu, siswa juga melatih mengomunikasikan apa yang dipelajari sebelumnya bersama teman sekelompoknya masing-masing. Cara memberikan kesempatan kepada siswa dilakukan dengan mengelilingkan tongkat sembari menyanyikan lagu. Siswa yang memegang tongkat ketika lagu yang dinyanyikan berhenti, siswa itulah yang memperoleh giliran untuk menjawab pertanyaan dari guru. Dalam hal ini, lirik lagu yang dibuat oleh guru itu sendiri 
menunjukkan materi yang sedang dipelajari. Guru bersama siswa mengevaluasi apa yang dikerjakan oleh temannya di depan, sehingga nantinya dalam mengkomunikasikan jawabannya siswa berhati-hati untuk menjawab dan memperhatikan setiap detail jawabannya. Terutama dalam penulisan simbol-simbol matematika ataupun satuan matematika. Dengan demikian kemampuan komunikasi matematika siswa ketika menjawab permasalahan berikutnya semakin baik dan kesalahan-kesalahan menggunakan simbol atau perhitungan juga dapat dikurangi. Hal ini sejalan dengan penelitian dari Ramayanti (2014) yang menyatakan bahwa hasil belajar matematika siswa yang dibelajarkan dengan model pembelajaran talking stick lebih baik dibandingkan dengan hasil belajar siswa yang dibelajarkan dengan pembelajaran konvensional. Dalam proses untuk mendapatkan hasil belajar yang baik diperlukan berbagai kemampuan yang harus dipahami siswa, misalkan pemahaman konsep ataupun kemampuan komunikasi. Dalam penelitiannya juga menjelaskan bahwa guru memberikan kesempatan yang luas pada siswa untuk membangun komunikasi antara siswa dengan teman sekelompoknya. Dengan demikian, siswa yang dibelajarkan dengan model pembelajaran talking stick bisa memiliki kemampuan komunikasi matematika yang lebih baik.

Selesai pembelajaran siswa diminta dan ditugaskan untuk melatih kembali membuat mind mapping, $\mathrm{Hal}$ ini dimaksudkan agar siswa lebih mengingat dan tertarik dengan mind mapping yang dibuat sendiri Karena dalam proses pembuatan mind mapping, pastinya siswa haruslah membaca terlebih dahulu, kemudian memahami secara perlahan. Secara tidak langsung proses menuliskan kembali ke dalam bentuk mind mapping akan melatih ingatan siswa terhadap materi. Hal ini sejalan dengan penelitian oleh Wowiling (2013) yang menunjukkan bahwa metode mind mapping memberikan pengaruh positif terhadap peningkatan penguasaan konsep siswa. Penguasaan konsep siswa berarti membuat siswa lebih paham dan siap jika siswa diberikan pertanyaan oleh guru. Sehingga berdampak pada kemampuan mengomunikasikan ideide matematika yang semakin membaik.

Dalam pembelajaran dengan model talking stick berbantuan mind mapping, guru berperan sebagai fasilitator mulai dari menyediakan mind mapping pada tahap awal pembelajaran, sampai lagu yang akan dinyanyikan siswa. Siswa lebih mandiri dalam belajar namun tetap dalam bimbingan dari guru apabila terdapat siswa yang kurang memahami pada diskusi kelompok tersebut. Menyediakan kondisi kelas yang menyenangkan, sehingga siswa tidak merasa bosan dalam mengikuti pembelajaran. Sedangkan pada pembelajaran konvensional, pada tahap awal guru menyajikan materi pelajaran, memberikan penjelasan dan siswa mencermati penjelasan guru tentang materi yang dibahas secara menyeluruh. Guru kemudian memberikan pertanyaanpertanyaan kecil pada siswa untuk memastikan siswa tetap mengikuti penjelasan, walaupun ada saja beberapa siswa yang tidak mengikuti pembelajaran dengan baik. Hal itu diatasi dengan memberikan pertanyaan-pertanyaan pada siswa yang terindikasi tidak memperhatikan, agar siswa tersebut mendengarkan untuk pembahasan selanjutnya.

Secara umum, pelaksanaan model pembelajaran talking stick berbantuan mind mapping dapat berjalan dengan baik dan sesuai rencana. Walaupun demikian, dalam pelaksanaannya di kelas tidak luput dari adanya kendala-kendala. Adapun kendalakendala yang dihadapi yaitu minimnya fasilitas LCD, hal ini dirasa penyampaian mind mapping akan lebih efektif apabila ditampilkan juga dalam layar dengan LCD, kemudian untuk mengatasi hal tersebut yaitu dengan memberikan mind mapping ke masing-masing kelompok. Selain itu, pada awal pelaksanaan siswa masih belum terbiasa dengan belajar kelompok sehingga terkadang adanya perselisihan antar teman, serta pada awal pelaksanaan yang mendapat giliran menjawab masih malumalu untuk mengungkapkan ataupun mengomunikasikan pendapatnya, hal ini dikarenakan kurangnya persiapan dalam belajar sebelumnya, namun setelah 
berlangsung pertemuan-pertemuan selanjutnya siswa mulai berani maju ke depan. Selalu memberikan penghargaan berupa nilai tambahan kepada siswa dan kelompoknya yang berani menjelaskan di depan kelas, hal ini mendorong motivasi siswa dan semangat serta keberanian untuk menjawab pertanyaan dari guru, selain itu membimbing di masing-masing kelompok dan menekankan pentingnya kerja sama yang baik dengan anggota kelompok dapat mengurangi adanya perselisihan.

Meskipun memiliki kendala dalam penerapannya dan kendala tersebut telah ditangani dengan baik, serta berdasarkan hasil pengujian hipotesis dan gambaran deskriptif yang diuraikan, model pembelajaran talking stick berbantuan mind mapping membawa dampak positif terhadap kemampuan komunikasi matematika siswa. Hal ini dibuktikan dengan hasil post test yang menunjukkan bahwa kemampuan komunikasi matematika siswa yang mengikuti pembelajaran dengan model pembelajaran talking stick berbantuan mind mapping lebih baik daripada kemampuan komunikasi matematika siswa yang mengikuti pembelajaran konvensional. Hasil penelitian ini juga menguatkan hasil penelitian dari Yunita (2014) yang menyatakan bahwa model pembelajaran talking stick berdampak positif terhadap kemampuan komunikasi matematika. Di mana terdapat perbedaan kemampuan komunikasi matematika siswa antara yang dibelajarkan dengan model pembelajaran talking stick dengan yang dibelajarkan menggunakan pembelajaran konvensional.

\section{SIMPULAN DAN SARAN}

Berdasarkan rumusan masalah, hasil analisis data, dan pembahasan penelitian yang telah diuraikan di depan, dapat disimpulkan bahwa terdapat pengaruh positif model pembelajaran talking stick berbantuan mind mapping terhadap kemampuan komunikasi matematika siswa. Hal ini ditunjukkan berdasarkan hasil perhitungan post test yang telah dianalisis dengan menggunakan uji-t satu ekor kanan pada taraf signifikan $5 \%$. diperoleh $t_{\text {hitung }}=2,11$ lebih dari $\quad t_{\text {tabel }}=1,671$.

Sehingga dapat disimpulkan bahwa kemampuan komunikasi matematika siswa kelas VIII SMP Negeri 6 Singaraja yang dibelajarkan dengan model pembelajaran talking stick berbantuan mind mapping lebih baik daripada kemampuan komunikasi matematika siswa kelas VIII SMP Negeri 6 Singaraja yang mengikuti pembelajaran konvensional.

Berdasarkan hasil penelitian, dapat diajukan beberapa saran yaitu (1) Kepada peneliti lain yang tertarik, disarankan jika melakukan penelitian terhadap model pembelajaran talking stick berbantuan mind mapping lebih efektif apabila selalu memperhatikan kendala-kendala yang telah diberikan agar nantinya dapat menyempurnakan penelitian. Terutama dalam menyampaikan materi melalui mind mapping agar memperhatikan waktu serta memaksimalkan waktu di sekolah dalam melatih siswa untuk membuat mind mapping. Selain itu menerapkan model pembelajaran talking stick berbantuan mind mapping dengan materi yang berbeda agar mengetahui pengaruh model pembelajaran talking stick berbantuan mind mapping dalam pembelajaran matematika secara lebih mendalam; (2) Kepada praktisi pendidikan matematika, khususnya guru mata pelajaran matematika diharapkan untuk menerapkan model pembelajaran talking stick berbantuan mind mapping sebagai salah satu alternatif pembelajaran di kelas mengingat pengaruh positif yang diberikan model pembelajaran talking stick berbantuan mind mapping terhadap kemampuan komunikasi matematika siswa.

\section{DAFTAR PUSTAKA}

Baroody, A.J. 1993. Problem Solving, Reasoning, and Communicating, K-8 Helping Children Think Mathematically. New York: Macmillan Publishing Company.

Candiasa. 2010b. Statistik Univariat dan Bivariat disertai Aplikasi SPSS. Singaraja: Unit Penerbitan Universitas Pendidikan Ganesha 
Departemen Pendidikan Nasional, 2006. Permendiknas Nomor 22 tentang Standar Isi untuk Satuan Pendidikan Dasar dan Menengah. Jakarta: Depdiknas.

Ebbutt, S. dan A. Straker. 1995. Mathematics in Primary Schools Part I:Children and Mathematics. London: Collins Educational Publisher Ltd.

IES.2016. "Highlights From TIMSS and TIMSS Advanced 2015". Tersedia pada

https://nces.ed.gov/pubs2017/201700 2 timss 2015 results.pdf (diakses tanggal 12 Januari 2017)

Iwan, Sugiarto. 2004. Mengoptimalkan Daya Kerja Otak dengan Berfikir Holistik dan Kreatif. Jakarta: Gramedia Pustaka Utama

Jakfar, Lukman dkk. 2015. "Analisis Soal Matematika TIMSS 2011 dengan Indeks Kesukaran Tinggi bagi Siswa SMP". Makalah disajikan dalam Seminar Nasional Pendidikan dengan tema Reformasi Pendidikan dalam memasuki ASEAN Economic Community (AEC). Universitas Jember, 30 Mei 2015. Tersedia pada http://repository.unej.ac.id/bitstream/h andle/123456789/62569/Artikel\%20S emnas $\% 202015 \% 20$ Lukman $\% 20 \% 2 \mathrm{~b}$ $\% 20$ Sertifikat.pdf?sequence $=1$ (diakses tanggal 12 Januari 2017)

OECD. 2016. "PISA 2015 Result in Focus What 15-year-olds Know and What They Can Do With What They Know". Tersedia pada http://www.oecdilibrary.org/pisa/keyfindings/pisa2015-results-overview.pdf (diakses tanggal 12 Januari 2017)

Ramayanti, M dan Evie Awuy. "Pengaruh Penerapan Model Pembelajaran Kooperatif Tipe Talking Stick Terhadap Hasil Belajar Matematika (Studi Eksperimen Pada Materi
Bilangan Bulat di Kelas VII SMPN 1 Sausu)". Tersedia pada http://jurnal.untad.ac.id/jurnal/index.ph p/JEPMT/article/download/7313/5893 (diakses tanggal 12 Januari 2017)

Shiel, G.et al. 2007. "PISA Mathematics: A Teacher's Guide". Dublin : Stationery Office. Tersedia pada http://www.sdpi.ie/inspectorate/insp p isa maths teach guide.pdf (diakses tanggal 12 Januari 2017)

Sugiyono. 2010. Metode Penelitian Kuantitatif, Kualitatif dan R\&D. Bandung:Alfabeta.

------. 2012. Statistika untuk Penelitian. Bandung: Alfabeta.

Sullvian, P dan Mousley. 1996. Natural Communication in Mathematics Classroom : Whats Does it Look Like. Melbourne: Merga.

Windura, Sutanto. 2008. Brain Management Series for Learning Strategys - Mind Map Langkah Demi Langkah. Jakarta: PT Alex Media Komputindo

Wowiling, Yoppy X. 2013. "Pengaruh Metode Pemetaan Pikiran (Mind Mapping) Terhadap Penguasaan Konsep Siswa kelas VIII pada Materi Kubus dan Balok". Tersedia pada http://kim.ung.ac.id/index.php/KIMFMI PA/article/view/11540/11411(diakses tanggal 12 Januari 2017)

Yunita, Cici Riska.2014. "Pengaruh Model Pembelajaran Talking Stick terhadap Peningkatan Kemampuan Komunikasi Matematik Siswa (Penelitian Eksperimen pada Siswa Kelas VII Semester Genap SMP Negeri 2 Tanjungsari-Sumedang". Tersedia pada http://digilib.uinsgd.ac.id/990/ (diakses tanggal 12 Januari 2017) 